subsided under load. Closure of the Mianlue suture marks the complete collision orogeny in the Qinling region. During Late Jurassic and Early Cretaceous, the northern Yangtze foreland belt thrusted southwards and converged with Wuling-Mufu belt in the Middle Yangtze in Late Jurassic and in Upper Yangtze in Early Cretaceous. The strata in the Yangtze foreland basin was gradually deformed from the east to the west, and depositional centers westward migrated to the northeast Sichuan basin in Late Jurassic and the northwest Sichuan basin in Early Cretaceous. Due to great compression, the Dabieshan arc-shaped thrust belt in the Middle Yangtze and the Dabashan arc-shaped thrust belt in the Upper Yangtze were formed.

From the above-geological data, it can be inferred that the Mianlue suture underwent processes of rifting from west to east and closing from east to west. The Yangtze plate subducted northwards and first collided with Qinling-Dabie plate at Dabieshan so that the ultrahigh pressure metamorphic rocks were formed (Li and Sun, 1996). During the process of collision, the Yangtze plate rotated clockwise relative to the Huabei plate. During Middle Jurassic the two plates collided straight. Subsequently, the Yangtze plate continued to press northwestwards, so that the northern Yangtze foreland belt continuously converged with Wuling-Mufu belt from east to west.
Dabieshan represents a major thrust, which overlapped or transformed continental marginal basin and foreland basin belts.

\section{References}

Li, S. and Sun, W. (1996) A Middle Silurian-Early Devonian magmatic arc in the Qinling mountains of central China: a discussion. J. Geol., v. 104, pp. 501-503.

Liu, S. and Zhang, G. (1999) Process of rifting and collision along plate margins of the Qinling orogenic belt and its geodynamics. Acta, Geologica. Sinica, v. 73, pp. 275-288.

Meng, Q.R., Yu, Z.P. and Mei, Z.C. (1997) Sedimentation and development of the forearc basin at southern margin of North Qinling. Scientia Geologica. Sinica, v. 32, pp. 136-145. (in Chinese with English abstract).

Mo, X. and Lu, F. (1993) The Sanjiang Tethyan volcanism and related mineralization. Geological Publishing House, Beijing, pp. 1-267.

Yin, H.F., Du, Y.S. and Xu, J.F. (1996) The discovery of radiolarian fauna in Mian-Lue suture zone of South Qinling and its palaeocean significance. Earth Science-J. China Univ. Geosci., v. 21, pp. 184184. (in Chinese).

Zhang, G.W., Meng, Q.R. and Lai, S.C. (1995) Tectonics and structure of Qinling orogenic belt. Science in China (Series B), v. 38, pp. 13791394.

Zhang, G.W., Meng, Q.R., Yu, Z.P., Sun, Y., Zhou, D.W. and Guo, A.L. (1996) Orogenesis and dynamics of the Qinling orogen. Science in China (Series D), v. 39, pp. 225-234.

\title{
Evidence for Archean Continental Crust in Northern Vietnam and its Implications for Tectonic Evolution in SE Asia
}

\author{
C.-H. Lo ${ }^{1}$, S.-L. Chung, ${ }^{2}$ C.-Y. Lan', T.-Y. Lee', H.-M. Li ${ }^{1}$, T. Nam ${ }^{5}$ and Y. Sano \\ 'Department of Geosciences, National Taiwan University, Taipei, Taiwan \\ ${ }^{2}$ Institute of Earth Sciences, Academia Sinica, Taipei, Taiwan \\ ${ }^{3}$ Department of Earth Sciences, National Taiwan Normal University, Taipei, Taiwan \\ ${ }^{4}$ Tianjin Institute of Geology and Mineral Resources, Chinese Academy of Geological Sciences, Tianjin, China \\ ${ }^{5}$ Hue University, Vietnam \\ ${ }^{6}$ Ocean Research Institute, University of Tokyo, Japan
}

Previous radiometric dating studies suggested that Southeast Asia, or, in a more strict sense, the Indochinese continent, is composed entirely of Proterozoic to Phanerozoic rocks and reliable evidence for Archean crust was lacking. Recently we reported $\mathrm{Sm}$-Nd isotopic data for eight basement rock samples collected in and around the Red River shear zone, northern Vietnam, and results for rocks from the Cavinh Complex which showed old Nd model ages in a range of 3.4-3.1 Ga. Two Cavinh samples were subjected to $\mathrm{U}-\mathrm{Pb}$ zircon dating by TIMS that yielded identical upper intercept ages of $\sim 2.83 \mathrm{Ga}$ indicating that the magmatic protoliths of the Cavinh complex were emplaced in the Archean. The results further show lower intercept ages ( 1.3 and $1.7 \mathrm{Ga}$ ) that may record the timings of subsequent metamorphic overgrowth and/or $\mathrm{Pb}$ loss of the zircon grains dated. This Archean protolith interpretation is now reconfirmed by new SHRIMP data, which yielded concordia $\mathrm{U}$-Pb zircon ages $(\sim 2.94-2.83 \mathrm{Ga})$ in the cores and $\sim 2.1 \mathrm{Ga}$ in the rims. Given the fact that during the mid-Tertiary sinistral movement of the Red River shearing the Indochina block was extruded southeastward for $-600 \mathrm{~km}$, the Cavinh Complex can be correlated to the Kangding Complex and therefore was originally located in the southwestern margin of the South China block. Consequently, the new data reinforce the argument for the presence of Archean rocks in the Indochinese continent, so that the Cavinh Complex represents one of the oldest crustal nuclei in the region, lending further support to our estimate of the left-lateral offset along the Red River shear zone that accounted for the extrusion tectonics in SE Asia. 